\title{
Medical Documentation in A Busy UK Teaching Hospital Eye Casualty - Is There Room for Improvement?
}

\author{
Edward John Ridyard* \\ Yorkshire Teaching Hospitals, UK
}

Submission: June 14, 2018; Published: August 16, 2018

*Corresponding author: Edward John Ridyard, Yorkshire Teaching Hospitals, UK Tel: 07969751627; Email: Edward-ridyard@doctors.org.uk

\begin{abstract}
The medical documentation surrounding adverse incidents is one of the first things to be reviewed. We set out to assess the quality of Medical Documentation in our Eye Casualty. A retrospective manual analysis of patient paper records was undertaken. The notes were randomly selected and evaluated using set of criteria compiled from a combination of NHSLA and NICE [1] guidelines. We found the standard of documentation was comparable to that of the previous audit cycle $(\mathrm{p}=0.03619)$. The expected standard was met for all elements of the guidelines and there were improvements in some areas. Overall the standard of documentation within Eye Casualty compared favourably to the expected standard. Methods of improving quality include increased education at local teaching and trainee inductions and in our unit this seemed to have a positive effect on maintaining a high standard.
\end{abstract}

Keywords: Medical; Documentation; Casualty; Standard; Quality

\section{Introduction}

When adverse events occur, documentation surrounding the incident is one of the first things to be reviewed. As a result, the UK NHS Litigation Authority [1] (NHS LA) and National Institute for Health Care and Excellence [1] (NICE) produced a set of guidelines for the expected standard of Medical Documentation. As part of the Ophthalmology team we set out to assess the quality of Medical Documentation in our Eye Casualty. This is something that has been audited in the department previously. Following on from the audit there has been a big push to increase awareness of the need for robust documentation, which has taken place at the induction of new junior doctors and Consultants as well as at Grand Round teaching.

\section{Methods}

The audit took the form of a retrospective manual analysis of patient paper records, there were no electronic paper records used in Eye Casualty at the time of the audit. Consent was gained from the departmental audit lead and no ethical approval was required prior to commencing the audit. The inclusion criteria were the patient being seen in Eye Casualty within a set twomonth period between 1st July 2016 and 1st October 2016. The notes were randomly selected and evaluated using set of criteria compiled from a combination of NHSLA and NICE [1]. guidelines seen in Table 1.
Table 1: Criteria for evaluating the standard of medical documentation.

\begin{tabular}{|l|l|}
\hline 1 & Notes should be dated \\
\hline 2 & Notes should be signed and have identifiable name \\
\hline 3 & Notes should contain a diagnosis (or differential) \\
\hline 4 & Notes should contain a management plan \\
\hline 5 & $\begin{array}{l}\text { Intraocular pressure should be measured where } \\
\text { appropriate }\end{array}$ \\
\hline 6 & Patients should be dilated where appropriate \\
\hline
\end{tabular}

\section{Results}

Table 2: Comparison of RCOphth expected guidelines to $1^{\text {st }}$ and $2^{\text {nd }}$ audit cycle results.

\begin{tabular}{|c|c|c|c|}
\hline Criteria & $\begin{array}{c}\text { Expected } \\
\text { Standard }\end{array}$ & $\begin{array}{c}\text { Aug } \\
\mathbf{2 0 1 4 ( n = 2 0 )}\end{array}$ & $\begin{array}{c}\text { Jan-16 } \\
\text { (n=20) }\end{array}$ \\
\hline $\begin{array}{c}\text { Notes should be } \\
\text { dated }\end{array}$ & $100 \%$ & $100 \%$ & $100 \%$ \\
\hline $\begin{array}{c}\text { Notes should be } \\
\text { signed and have } \\
\text { identifiable } \\
\text { name }\end{array}$ & $100 \%$ & $100 \%$ & $100 \%$ \\
\hline $\begin{array}{c}\text { Notes should } \\
\text { contain a } \\
\text { diagnosis (or } \\
\text { differential) }\end{array}$ & $100 \%$ & $100 \%$ & $100 \%$ \\
\hline
\end{tabular}




\begin{tabular}{|c|c|c|c|}
\hline $\begin{array}{c}\text { Notes should } \\
\text { contain a } \\
\text { management } \\
\text { plan }\end{array}$ & $100 \%$ & $100 \%$ & $100 \%$ \\
\hline $\begin{array}{c}\text { Intraocular } \\
\text { pressure should } \\
\text { be measured } \\
\text { where } \\
\text { appropriate }\end{array}$ & $80 \%$ & $30 \%$ & $90 \%$ \\
\hline $\begin{array}{c}\text { Patients } \\
\text { should be } \\
\text { dilated where } \\
\text { appropriate }\end{array}$ & $80 \%$ & $50 \%$ & $72 \%$ \\
\hline
\end{tabular}

The data set was tested for normality using KolmogorovSmirnoff testing and the current and previous audit cycles were compared using the paired t-test. We found the standard of documentation was comparable to that of the previous audit cycle $(p=0.03619)$. In some areas such as documenting intraocular pressure and dilating where appropriate there was an improvement (Table 2). The expected standard was met for all elements of the guidelines.

\section{Discussion}

As clinician's medical documentation is one of the first things to suffer when we become stressed or busy. However, it forms the foundation of a medico-legal defence. The mantra "if it isn't documented, it didn't happen" should always be in the forefront of the mind of a clinician.

\section{Conclusion}

Overall the standard of documentation within Eye Casualty compared favourably to the expected standard. This study highlights the benefit of improving the quality of medical documentation by having increased education at local teaching and trainee inductions. This study agrees with other studies that show that improved education improves medical documentation standard and doctor's performance [2]. A proforma specifically designed for clerking Eye Casualty patients should also be introduced as a useful aide-memoire for the busy Eye Casualty setting to ensure that standards are maintained.

\section{Acknowledgement}

This author has no conflict of interest to disclose.

\section{References}

1. (2018) NHS Litigation Authority - GOV.UK.

2. Mann R, Williams J (2003) Standards in medical record keeping. Clinical Medicine 3: 329-332.

\section{Your next submission with Juniper Publishers will reach you the below assets}

- Quality Editorial service

- Swift Peer Review

- Reprints availability

- E-prints Service

- Manuscript Podcast for convenient understanding

- Global attainment for your research

- Manuscript accessibility in different formats

( Pdf, E-pub, Full Text, Audio)

- Unceasing customer service

Track the below URL for one-step submission https://juniperpublishers.com/online-submission.php 